\title{
Content and Language Integrated Learning Practice in English for Accounting Course
}

\author{
Arif Nugroho, arif.nugroho@iain-surakarta.ac.id, IAIN Surakarta Indonesia
}

\begin{abstract}
The contextualization of materials in the context of teaching English for specific purposes (ESP) is a prerequisite to gain maximum input of language knowledge. The present study sheds some light on the practice of Content and Language Integrated Learning (CLIL) approach in English for accounting course. This study involved 38 Indonesian ESP students majoring in accounting of a public university in Surakarta Indonesia as the participants. Pre-experimental research design was conducted in eight meetings during the course, including the administration of vocabulary test to examine the participants' score in pre-test and post-test. A focus group discussion (FGD) was also carried out to reveal the students' perception about the practice of CLIL approach in English for accounting course. The results depicted that there was a significant difference on the participants' vocabulary scores between the pre-test and the post-test. It was also portrayed that the participants positively perceived the CLIL practice in their class. The results of this study contribute to providing fruitful insights for teachers and future researchers about CLIL practice in English language teaching, specifically in the context of teaching English for specific purposes.

Keywords: CLIL practice, English for Accounting, English for specific purposes
\end{abstract}

\section{A. INTRODUCTION}

The twenty-first century global competition has encouraged the necessity of English proficiency among the graduates of higher education institutions. In the Association of Southeast Asian Nations (ASEAN) region, English is considered as a lingua franca commonly used as a means of communication among ASEAN people. The fact that English becomes a connecting language of people in the world has triggered universities to integrate the language in a curricula, not only in English department but also in nonEnglish department. It is believed that performing an excellent English proficiency is a guarantee to achieve a promising job (Nartiningrum and Nugroho 2020), including accounting field. Additionally, the demand for professional workers in 2030 is predicted to increase as many as three times than the last decade (Handayani 2015). Therefore, English communication ability is a prerequisite skill that should be possessed by undergraduate students in the near future to ensure their active involvement in the global working environment.

Notwithstanding the fact that having an excellent English skill is crucial, many Indonesian students including the participants of this study undeniably have limited English proficiency and lack of motivation in practicing the language (Simbolon and Nurmala 2015; Nugroho 2020). The possible reason of this limitation can be the fact that English is considered as a foreign language in Indonesia. By this context, the most frequent place that the learners are exposed to the language is a formal classroom (Nugroho et al.

172 | IJET| Volume. 9, Issue 2. December 2020 Copyright 2020 Arif Nugroho is licensed under Creative Commons Atrribution- ShareAlike 4.0 International License. 
2020). English is officially exist in educational institutions (e.g. schools and universities) as a subject or additional course (Luo and Garner 2017). In this context, English is considered as a specific purpose (ESP) for accounting students. Hence, content and language integrated learning (CLIL) that performs a dual-focus (e.g. language and content) is appropriate to be conducted in an ESP context.

In the context of English language teaching (ELT), English for specific purposes (ESP) is considered as teaching English for students of a particular field of study in which the teaching materials are based on the purposes of a subject matter curriculum (Hutchinson and Waters 1987; Basturkmen 2014). An ESP class is designed to meet the students' needs of language knowledge and skills to support the development of their future careers in working environment (Nugroho and Rekha 2020). As a result, the ESP teaching and learning should concern on assisting the students to enhance language proficiency according to their own field of studies. Hence, ESP classes must be an opportunity for students to obtain a lot of exposure of English as an effort to gain a promising future career in international working environment (Poedjiastutie 2019).

Similar to ESP approach, the term content language integrated learning (CLIL) is a teaching approach focusing on language component and content knowledge (Coyle 2010). CLIL is a dual focused teaching approach where integrating language components in the teaching and learning of content knowledge is the primary objective (Coyle, Hood, and Marsh 2010). CLIL has received a huge attention of ELT scholars in Europe since its emergence as a means of two additional language learning in addition to the mother tongue (British Council, 2014), however, its implementation still remains more paucity of evidence in Indonesia (Floris 2013). Conducting teaching and learning activities by integrating CLIL approach needs collaboration among English language and content teachers as an effort to gain general and specific themes in the particular field to be conveyed to the learners (Simbolon and Nurmala 2020). In response to the issue, therefore, this study examines CLIL practice in the context of teaching English for specific purposes in Indonesia.

In the recent decades, studies on CLIL practice have been conducted and the results show several supports for this approach in the context of English language teaching. A study carried out by (McDougald 2015) about CLIL practice in Columbian context revealed that language teachers actively sought to formal and informal instruction in CLIL. Most of the teachers positively perceived the implementation of CLIL in Columbian language teaching and agreed that CLIL approach could benefit the students to develop both subject knowledge and language skills. In the context of teaching English for specific purposes, (Fazio, Isidori, and Bartoll 2015) examined the implementation of CLIL method in teaching Physical Education (PE) in English as a lingua franca in European context. The results depicted that CLIL method could potentially be conducted by integrating a cultural content based on language and knowledge.

Moreover, (Aiello, Di Martino, and Di Sabato 2017) began to open a window into Italian content and language integrated learning teachers' language competence and how CLIL was being assessed in a language learning. The research reported the description of detailed specific decision-making process with regards to the evaluation of CLIL practice in Italian English language teaching context. More recently, (Yalçın, Bayyurt, and Alahdab 
2020) investigated how CLIL practice at English classrooms enhanced the teachers' awareness toward their use of language as seen from English as a lingua franca perspective. Through a survey about the teachers' CLIL practices in language classrooms, the results showed that the teachers encountered several challenges in implementing CLIL in their classrooms. However, their experiences encouraged the teachers to be more aware of three major components of EFL awareness, i.e. awareness of instructional practice, awareness of learning, and awareness of language use.

In Indonesian EFL context, several studies about CLIL practices have also been conducted. Among them, a study done by Puspitasari (2018) reported a positive perception of university learners toward CLIL learning tasks. The learners acknowledged that collaborative activities such as group discussion and presentation significantly contribute to the positive perspective. Another study was performed by (Fitriani 2016) in Indonesian tertiary education context. She investigated CLIL experience of university students in English as a foreign language class. This study portrayed several improvements achieved by the students in their English language through CLIL practices. Above all, previous studies in the area of CLIL practice in Indonesian EFL context indicated promising outcome and positive perceptions, both in the side of teachers and students.

Having explored the above-mentioned previous literature, a research gap is observable. Notwithstanding the fact that CLIL practice has been examined in most of English language teaching contexts, the implementation of CLIL approach in teaching English for accounting still remains unexplored. Examining CLIL practice in English for accounting classroom is crucial since this department is receiving a great number of attention from stakeholders. Equipping accounting students with adequate knowledge and skills of English is a strategic way to improve the level of competitiveness in international working environment. Therefore, the present study is at the cutting edge of investigating the promising impact of CLIL practice in an English for accounting course and examining the students' perspectives toward the implementation of this approach. To ensure the objectives, this study is guided under two research questions; (1) does CLIL practice improve accounting students' achievement in English? and (2) what are students perceptions of CLIL practice in their English for accounting course?

\section{B. METHOD}

The primary objective of the in-hand study is to shed some light on the implementation of CLIL practice to enhance accounting students' English language skills and knowledge. A secondary aim of this study is to portray the students' perceptions of CLIL practice in their English class. To this end, an experimental research was adopted. Experimental research is a scientific approach, where one or more independent variables are manipulated and applied to one or more dependent variables to measure their effect (Mao and Yang 2019). In the context of this study, the experimental design was employed to seek the answer of the first research question that was examining the impact of CLIL practice on the students' language competence. Following the results of experimental research, this study made use of FGD to depict the qualitative data to reveal more in-depth 
understanding of the students' perceptions about the CLIL practice. The FGD was administered in order to answer the second research question.

This study was based in Indonesian ELT context where English is considered as a foreign language. The most available place where the students obtain great exposure of English is only a formal classroom (Nugroho and Nartiningrum 2020). This study was conducted in English for accounting course of first-year students at IAIN Surakarta Indonesia at odd semester of academic year 2019/2020. The English course is a compulsory subject that should be taken by all accounting students in the aim to equip the students with specific purposes and needs of English knowledge and skills. The participants involved in this study were 38 accounting students, consisting of 20 (53\%) female and $18(47 \%)$ male. All participants are native speaker of Indonesian. They were taking an undergraduate program and their average age was 18 .

The present study employed a pre-test and post-test on English vocabulary to see the improvement of students' performances in English vocabulary related to accounting field. A FGD was also conducted to reveal the students' perceptions on the implementation of CLIL approach. First of all, the participants were required to fulfill a pre-test about vocabulary exercise related to accounting that consisted of 20 questions in multiple choice. All the question items were designed by referring to terms and vocabularies that often used in accounting field and working environment. After conducting the pre-test, the participants were taught by using CLIL approach for 6 meetings. The participants were taught language component focusing on vocabulary and some English skills that were closely related to accounting such as vocabulary in context, reading for accounting topic passages, writing financial reports, speaking formal and informal conversation using accounting vocabulary, etc. In the eighth meeting, another series of vocabulary test consisting of 20 questions was administered to see the participants' improvement after being taught using CLIL approach. Second, a FGD was conducted with 8 students to reveal their perception about the practice of CLIL approach in their class. The FGD last for 90 minutes in which each student had a chance to deliver their opinion about the topic being discussed. An interesting discussion among participants was also taken place by the guidance of the researchers.

Two raters were involved in scoring the results of pre-test and post-test. The first rater was one of the researcher and the other rater was an accounting lecturer at IAIN Surakarta Indonesia. The participants' scores in English vocabulary tests were converted into 1-100 based on the number of the correct answers. The mean score, along with standard deviation and standard error mean, of the pre-test and post-test were calculated by means of SPSS. To determine whether the two mean scores have significant difference, a paired sample t-test was administered. Moreover, the results of FGD were noted and coded to see the emerging theme based on the research question of this study. During the process of coding, the researchers simplify, analyze, and reviewed the most relevant data that later were used as a basis of conclusion drawing. 


\section{RESULTS AND DISCUSSION}

This section deals with the results of data analysis and the discussion related to the results. This section is presented in two parts. The first part depicts the result of data analysis to answer the first research question and the second part focuses on the answer of the second research question. The participants' utterances are quoted verbatim to support the delineation of the findings. Interpretation and relation of the results to current theories and previous findings are also presented as part of discussion.

\section{a. Impact of CLIL Practice on Students' Vocabulary Acquisition}

The first result of data analysis is about the impact of CLIL practice on accounting students' scores in English vocabulary. The mean scores of the pre-test and post-test are calculated to examine the students' improvement. The data of the results of pre-test and post-test is presented in table 1 .

Table 1. Results of Pre-test and Post-test

$\begin{array}{lllll} & \text { Mean } & \text { N } & \text { Std. Deviation } & \text { Std. Error Mean } \\ \text { Pre-test } & 61.3177 & 38 & 5.677023 & 2.134116 \\ \text { Post-test } & 76.5823 & 38 & 10.46732 & 1.197374\end{array}$

Table 1 portray the difference between the participants' scores of pre-test and posttest. The mean score of the participants in pre-test is 61.3177 , while the mean score in the post-test is 76.5823 . In order to depict whether the two mean scores have a significant difference, a paired sample t-test is conducted. The results of paired sample t-testanalysis can be seen in table 2 .

Table 2. Results of Paired Sample t-test

\section{Paired Differences}

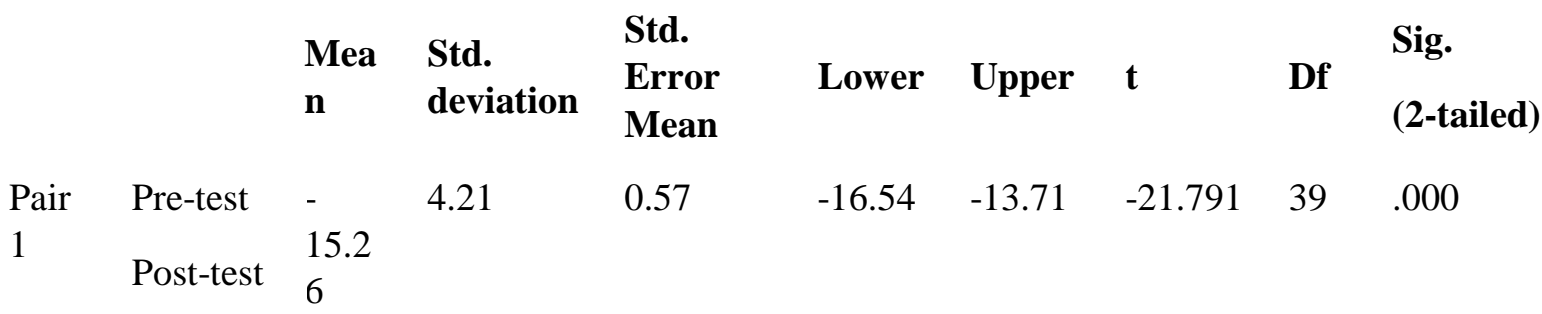

Interval of the

Difference
95\% Confidence

Table 2 shows that the participants' score in the post-test emphasizes the significant different compared to the results of pre-test. The participants achieve better performance in the post-test after being taught using CLIL approach in their class. As presented in table 2 , the t-test statistics is -21.791 and the significant level is $.000(<.05)$, which means that there is a significant difference between the participants' scores of pre-test and post-test. The table also portray that the average score of the participants in the post-test is 15.26 points higher than the pre-test. Hence, this result suggests that the null hypothesis is

176 | IJET| Volume. 9, Issue 2. December 2020 Copyright 2020 Arif Nugroho is licensed under Creative Commons Atrribution- ShareAlike 4.0 International License. 
rejected. Above all, it can be concluded that the accounting students involved in this study who are taught using CLIL approach experience significant improvement on their English vocabulary acquisition.

The improvement of the students' English competence after experiencing CLIL practice as resulted in this study confirms the results of previous studies reported by (Fazio, Isidori, and Bartoll 2015; McDougald 2015). These studies reveal that CLIL approach can potentially be conducted both in the context of English as a second language and a foreign language. In general, CLIL approach has received a good attention from the perspectives of teachers' and students. The possible reason for the positive acceptance is that CLIL is contextual and can be implemented in various context of English language teaching (San et al. 2019; Rachmajanti and Anugerahwati 2019), including teaching English for specific purposes as conducted in this study. By the results, ELT scholars should begin to pay more attention on the use of CLIL approach to gain adequate inputs of language components and content knowledge for students.

Drawing on CLIL practice in European context, the study conducted by (Bower 2019) reports school leaders' perspectives on content language and integrated learning in three state secondary schools in England. The results suggest that the school leaders are willing to gain responsibility for developing CLIL based language learning activities to be integrated in school curricula. The study of (Bower 2019) is clearly supported by the present study's finding which indicates that CLIL practice is a promising educational approach to promote the success of language learning both in the context of English as a second language and a foreign language. In the context of teaching English for specific purposes, the result of this study is also consistent with what have been reported by (Kirsanova and Lazarev 2019) who examine the practice of CLIL approach in English for engineering of Russian English language teaching. The implementation of CLIL in the engineering class contributes to the development of students' communicative competence that is similar to the results of this study. The difference between the study of (Kirsanova and Lazarev 2019) and this study is only the subject of the research in which this study made use of English for accounting class to conduct CLIL practice. Besides the difference, the results of both studies indicate that CLIL practice can be an alternative teaching approach to gain the success of ESP teaching in various fields of study.

b. Students' Perception toward CLIL Practice in English for Accounting Course

The results of focus group discussion depict the participants' perceptions of the practice of CLIL approach in their English for accounting class. In general, the participants convey positive perspectives about several aspects of CLIL practice in English course. More than half of the participants state that learning English using CLIL approach enable them to acquire more about the content knowledge. The CLIL approach seems to provide the participants access to more particular vocabulary and terminology that often appear in their field of study. The participants in FGD expresses their opinion as follows (the name is initials):

"During the CLIL practice in my class, I think that I am more familiar with some vocabulary and terminology in accounting that I do not know before. My teacher introduce me and my classmates a range of vocabulary and passages 
in English such as accounting profession, terms in financial report and bookkeeping, and vocabulary in finance." (ARF. FGD)

"I can learn and memorize more vocabulary in accounting since my teacher give a lot of exposure about that through passage, videos, games, etc." (RK. FGD)

This finding is relevant to the results of a study reported by (Fitriani 2016) in which EFL students perform an improvement in their learning outcomes in terms of English vocabulary. The enhancement in vocabulary competence as one of the most crucial language components offers a valuable opportunity for the students to gain knowledge about the content. Hence, the knowledge of English vocabulary is a key success of understanding and acquiring the content knowledge (Khoiriyah 2020; Setyaningrum, Rina, and Purwati 2020).

Another interesting point that is resulted from the FGD is that learning English through CLIL approach is easy and fun. As revealed from the FGD, the reason is that the use of technology enhanced language learning such as Quizzes and Kahoot as media to grab the participants' attention. It appears to be a proper strategy to be integrated in a CLIL practice, so that the students' motivation can be maintained. In relation to this, some students express their utterances.

"I find that the teaching and learning using CLIL in my class is fun. I enjoy the teaching activities because my teacher use games using Quizzes and Kahoot." (LN. FGD)

"The materials in my English class become easier to be understood because my teacher integrate them in games like using Kahoot. It is interesting and I do not get bored." (GS. FGD)

This finding is in line with what have been found by (Simbolon and Nurmala 2020) that CLIL practice in English for specific purposes context offers the students opportunity to experience joyful, fun, and easy learning activities. Twenty-first century students are well-known as digital natives, so that integrating technology in a language learning can be an alternative to enhance their learning motivation (Lee and Dressman 2018). The integration of technology in ELT context is a promising way to achieve the success of a language learning (Atmojo, Eko, and Nugroho 2020; Lee 2019). This is proven by the

results of this study that the students can maintain their learning motivation during the process of CLIL practice in their English for accounting class using technology integration.

The results of this study have several implications for English language teaching. First, revealing the positive impact of CLIL approach on language learners' skills is a compelling effort to seek an alternative of teaching approach to develop language learners' communicative competence. Drawing on the results of this study and several previous relevant findings, English teachers can design teaching activities based on the integration of language and content knowledge. Second, the results of this study become 'a wake-up call' for English teachers and school administrators to begin acknowledging the potential benefit of CLIL practice in English language teaching, particularly in the context of teaching ESP. In this regards, the present study supports that CLIL approach can be integrated in the school curricula of English language teaching in Indonesia as also suggested by Bower (2019) in the English curricula in European context.

178 | IJET| Volume. 9, Issue 2. December 2020 Copyright 2020 Arif Nugroho is licensed under Creative Commons Atrribution- ShareAlike 4.0 International License. 


\section{CONCLUSION}

The in-hand study aims to examine the CLIL practice in English for accounting course at IAIN Surakarta Indonesia. The results of data analysis reveal that CLIL practice can significantly enhance English competence of accounting students, particularly vocabulary acquisition. Through focus group discussion, the participants convey positive perception toward the implementation of CLIL approach in their English class. These results contribute to providing a fruitful insight for English teachers about CLIL practice especially in teaching English for specific purposes context. Apart from these compelling results, the participants of this study suggest to add more various learning materials that can enhance their content knowledge. Therefore, future studies are recommended to integrate a more complex variety of learning materials in a CLIL practice. As an effort to confirm the results of this study, it is also suggested that future studies examine other related fields of teaching English for specific purposes such as business management, economic development, and banking.

\section{E. REFERENCES}

Aiello, Jacqueline, Emilia Di Martino, and Bruna Di Sabato. 2017. "Preparing Teachers in Italy for CLIL: Reflections on Assessment, Language Proficiency and Willingness to Communicate." International Journal of Bilingual Education and Bilingualism 20, no. 1: 69-83.

Atmojo, Arief, Priyo Eko, and Arif Nugroho. 2020. "EFL Classes Must Go Online! Teaching Activities and Challenges during COVID-19 Pandemic in Indonesia." Register Journal 13, no. 1: 49-76. https://doi.org/10.18326/rgt.v13i1.49-76.

Basturkmen, Helen. 2014. Ideas and Options in English for Specific Purposes. USA: Routledge.

Bower, Kim. 2019. “School Leaders' Perspectives on Content and Language Integrated Learning in England." Language, Culture and Curriculum, 1-17.

Council, British. 2014. Corporate Plan 2014. London: British Council.

Coyle, Do. 2010. CLIL: A Pedagogical Approach from the European Perspective. Second and Foreign Language Education: Encyclopedia of Language and Education Volume 4. Springer Science+ Business Media.

Coyle, Do, Philip Hood, and David Marsh. 2010. Content and Language Integrated Learning. Ernst Klett Sprachen.

Fazio, Alessandra, Emanuele Isidori, and Óscar Bartoll. 2015. "Teaching Physical Education in English Using CLIL Methodology: A Critical Perspective." Procedia-Social and Behavioral Sciences 186: 918-26.

Fitriani, Ika. 2016. "Grass Roots' Voices on the CLIL Implementation in Tertiary Education." Dinamika Ilmu 16, no. 2: 211-20.

Floris, Flora Debora. 2013. "Learning Content Subjects Through English: Indonesian High School Students' Voices.” The New English Teacher 7, no. 1. 
Handayani, Titik. 2015. "Relevansi Lulusan Perguruan Tinggi Di Indonesia Dengan Kebutuhan Tenaga Kerja Di Era Global.” Jurnal Kependudukan Indonesia 10, no. 1: $53-64$.

Hutchinson, Tom, and Alan Waters. 1987. English for Specific Purposes. Cambridge university press.

Khoiriyah. 2020. "CALL and SLA Theory: Developing A Framework to Analyze WebBased Materials for Teaching Listening Skills.” IDEAS: Journal on English Language Teaching and Learning, Linguistics and Literature 8, no. 1.

Kirsanova, Galina, and Vladimir Lazarev. 2019. Content and Language Integrated Learning: A New Approach to Teaching Engineering. Handbook of Research on Engineering Education in a Global Context. IGI Global.

Lee, Seong. 2019. "Quantity and Diversity of Informal Digital Learning of English." Language Learning and Technology 23, no. 1: 114-26. https://doi.org/10.125/44675.

Lee, Seong, and Mark Dressman. 2018. "When IDLE Hands Make An English Workshop: Informal Digital Learning of English and Language Proficiency." Tesol Quarterly 52, no. 2: 435-45.

Luo, Jing, and Mark Garner. 2017. "The Challenges and Opportunities for English Teachers in Teaching ESP in China." Journal of Language Teaching and Research 8, no. 1: 81. https://doi.org/10.17507/j1tr.0801.10.

Mao, Z C, and S L Yang. 2019. "International Perspectives on Teaching the Four Skills in ELT: Listening, Speaking, Reading, Writing." System 81: 214-16.

McDougald, Jermaine. 2015. "Teachers' Attitudes, Perceptions and Experiences in CLIL: A Look at Content and Language." Colombian Applied Linguistics Journal 17, no. 1: 2541 .

Nartiningrum, Novrika, and Arif Nugroho. 2020. "Developing English Teaching Materials for Accounting Students: An ESP Approach." PROJECT (Professional Journal of English Education) 3, no. 4: 434. https://doi.org/10.22460/project.v3i4.p434-442.

Nugroho, Arif. 2020. "English Material Needs of Accounting Students : An English for Specific Purposes Approach.” Internation Journal of Research in English Education 4778: 1-15. https://doi.org/10.24256/ideas.v8i1.1239.

Nugroho, Arif, and Novrika Nartiningrum. 2020. "Classroom Activities for Teaching Speaking: Voice of Indonesian EFL Learners." Journal of Language Teaching and Research 9, no. 1: 35-46. https://doi.org/10.31571/bahasa.v9i1.

Nugroho, Arif, and Agnira Rekha. 2020. "Speech Acts of Requests: A Case of Indonesian EFL Learners." Journal of English Language Teaching and Linguistics 5, no. 1: 1-16.

Nugroho, Arif, M Zamzami, Akbar Rizal, and Ukhrowiyah. 2020. "Language Input, Learning Environment, and Motivation of A Successful EFL Learner." Journal on English as a Foreign Language 10, no. 1: 46-69. https://doi.org/10.23971/jefl.v10i1.1511.

Poedjiastutie, Dwi. 2019. "English Communication Needs of Engineering Students." International Journal of Language and Linguistics 7, no. 2: 69. https://doi.org/10.11648/j.ijll.20190702.13. 
Puspitasari, Evi. 2018. "Classroom Activities in Content and Language Integrated Learning." Journal of Foreign Language Teaching and Learning 1, no. 2: 1-13.

Rachmajanti, Sri, and Mirjam Anugerahwati. 2019. "Predictor of the Students' English Achievement at Lower Secondary School: CLIL Context." Teflin Journal 30, no. 1: 7287.

San, Isidro, Xabier, Lasagabaster, and David. 2019. "Monitoring of Teachers' Views on Both CLIL and the Development of Pluriliteracies: A Longitudinal Qualitative Study." English Language Teaching 12, no. 2: 1-16.

Setyaningrum, Wahyu Rina, and Oikurema Purwati. 2020. "Projecting the Implementation Feasibility of CLIL Approach for TEYL at Primary Schools in Indonesia." JEES (Journal of English Educators Society) 5, no. 1: 23-30.

Simbolon, and Elmin Nurmala. 2015. "Using the CBI Method in Teaching English in an Indonesian University.” Pertanika Journal of Social Sciences \& Humanities 23, no. 4.

Simbolon. 2020. "CLIL Practice in A Maritime English Course : EFL Students' Perception." Journal of Curriculum and Teaching 5, no. 2: 263-76.

Yalçın, Şebnem, Yasemin Bayyurt, and Rifaioğlu Alahdab. 2020. "Triggering Effect of CLIL Practice on English as A Lingua Franca Awareness.” ELT Journal. 